\title{
Study and Sizing of a Drip Irrigation System by Photovoltaic Pumping in the District of Bellel, Mamou
}

\section{Prefecture}

\author{
${ }^{1}$ Amadou Diarra, ${ }^{2}$ Ansoumane Sakouvogui, ${ }^{3}$ Mariame BAH, ${ }^{4}$ Mamby Keïta \\ ${ }^{1}$ Department of Mechanical Engineering, Gamal Abdel Nasser University of Conakry, Guinea \\ ${ }^{2}$ Energy Department, Higher Institute of Technology of Mamou, Guinea \\ ${ }^{3}$ Mechanical Design and Manufacturing Department, Higher Institute of Technology of Mamou, Guinea \\ ${ }^{4}$ Department of Physics, Gamal Abdel Nasser University of Conakry, Guinea
}

\begin{abstract}
The objective of this study is to design a drip irrigation system by photovoltaic pumping of a plot distributed in the sector of the plain of vegetable crops (tomato, corn, potato and eggplant) of Bellel, prefecture of Mamou. The various results obtained during this study mainly relate to the determination of the meteorological parameters (temperature, solar irradiation, precipitation and relative humidity) of the site, the daily water requirements $(150 \mathrm{~m} 3)$ for the irrigation of 7 hectares, of which $50 \mathrm{~m}^{3}$ for each crop plot $(2,333$ hectares) divided into 4 sectors, the geometric dimensions of the drip irrigation system (67 booms for each sector for a total of 268 booms, 63 drippers per boom, i.e. 31 pairs of drippers per boom), the dimensions of the pumping system (HMT is $10.45 \mathrm{~m}$, daily flow of each pump $58.517 \mathrm{~m}^{3}$ or $14.203 \mathrm{~m}^{3} / \mathrm{h}$, energy consumed by each motor pump 4443.586 Wh/d, the power of the inverter $4677.459 \mathrm{Wh} / \mathrm{d}$ and the peak power of the PV system $1090.825 \mathrm{Wh} / \mathrm{d})$. The characteristics of the photovoltaic field (type of solar panel Cip-80-315 of unit peak power $315 \mathrm{Wp}$, total power of the field 4728.24 Wp, voltage per branch 199 volts and total current in the parallel connection $23.76 \mathrm{~A}$ ). The $\mathrm{PV}$ array is made up of 5 modules in series and 3 in parallel, for a total of 15 modules. The installation diagram for the entire system has been completed. It emerges from this feasibility study that the results obtained will serve as a basis for the design and implementation of a drip irrigation system by photovoltaic pumping for market garden crops throughout the plain of Bellel in particular and in general for the Guinea.
\end{abstract}

Keywords: Sizing, drip irrigation, pumping, photovoltaic.

\section{INTRODUCTION}

Water and energy are important, essential and indispensable elements for life. Access to water resources and to clean and sustainable energies is one of the major challenges of the $21 \mathrm{st}$ century [1]. The galloping demography, the search for well- being and economic development in sub-Saharan Africa imply an increase in water needs for domestic consumption, for livestock and agriculture and for industry [2].

The development of irrigated agriculture is essential to achieve the objectives of long-term food strategies. Irrigated agriculture faces many challenges in terms of production and profitability. Irrigation is considered to be one of the cultural practices that the farmer has to manage. It has long been an essential component of agriculture. The greatest advances in agriculture have been obtained through irrigation [3].

In Europe, agriculture accounts for $24 \%$ of water use [4]. Agriculture is the main sector of activity for nearly $80 \%$ of the Guinean population. It is highly dependent on rainfall. In fact, rainfed crops occupy $95 \%$ of the sown areas. Irrigated crops occupy only 30,200 ha on a potential irrigable land estimated at 364,000 ha. Family-type farms occupy $60 \%$ of the population and represent $95 \%$ of cultivated areas. They are generally small, between 0.3 and 1.5 hectares [5].

Drip irrigation remains the most suitable technique for managing water resources. However, the energy resource that it requires for its implementation remains a whole problem. Because this implies an increase in demand for conventional energy of fossil origin which is increasingly drying up. One of the practical, clean and sustainable solutions for acquiring energy in Guinea is the use of renewable energies with unlimited resources from the sun, the wind, the heat of the earth [6].

Photovoltaic energy, the most recent renewable energy, has the advantage of being non-polluting and usable in isolated rural areas far from the urban electricity grids which are in deficit [7]. In Africa, studies have been carried out by several authors on drip irrigation systems using photovoltaic pumping [3].

Drip irrigation or localized irrigation, also called microirrigation, is the supply of localized water near the roots of 
plants, with reduced doses but at high frequencies. In principle, localized irrigation is in fact only an improvement of traditional techniques [8]. The drip saves water (50 to $70 \%$ compared to gravity and $30 \%$ compared to sprinkling) and the use of fertigation. It contributes to an increase in yields, of the order of 20 to $40 \%$ and to the improvement of the quality of market garden products. Compared to other irrigation systems, drip irrigation allows a reduction in energy expenditure used in pumping, a reduction in the cost of labor involved in irrigation operations, and a reduction in costs. quantities of fertilizers used $[9,10]$.

In some agricultural areas of Guinea, drip irrigation systems are installed, powered by generators (motor pumps) for pumping water. But today, this photovoltaic pumped drip irrigation system has not been studied. Hence the objective of this work, the study and sizing of a drip irrigation system by photovoltaic pumping in the village of Bellel, Mamou prefecture.

\section{MATERIALS AND METHODS}

\subsection{Materials}

\section{a. Presentation of the study area}

This study took place in the prefecture of Mamou located $270 \mathrm{~km}$ from the capital Conakry between $10^{\circ} 23^{\prime}$ north, $12^{\circ} 05^{\prime}$ west at an average altitude of $700 \mathrm{~m}$. With a climate characterized by the alternation of two seasons of the same duration, the dry season from November to April and the rainy season from May to October, precipitation varies between $1600 \mathrm{~mm}$ and $2000 \mathrm{~mm}$, with an average annual temperature of $25^{\circ} \mathrm{C}$. . It covers an area of $8000 \mathrm{~km}^{2}$ with a population of 318738 in habitants (2014) [11].

The annual rainfall is around $1681 \mathrm{~mm} 3$. The average humidity varies between 65 and $67 \%$. The prevailing winds are harmattan and monsoon. The soils are varied, including ferralitic mountain soils, hydro-morphic soils and skeletal soils. The relief is rugged, made up of a plateau forming the Fouta Djallon massif [12].

The study site is the agricultural market gardening zone of Bellel in the district of Dara, sub-prefecture of Timbo, prefecture of Mamou. It is located $45 \mathrm{~km}$ from downtown Mamou. The area of the agricultural site is 14 ha occupied by two (2) groups. The different crops grown on the site are: Rice occupies half of the site and market gardening crops (tomato and eggplant) to which our study relates (figure 1) occupies the other half (7 ha).

The meteorological parameters (temperature, precipitation and relative humidity) of the site are obtained from calculations of data from the Gbessia meteorological station in Conakry for the Mamou area.

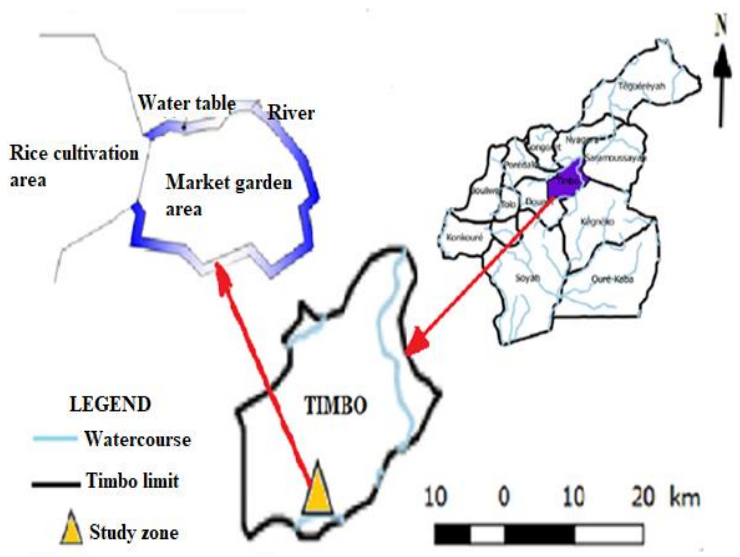

a) Study area

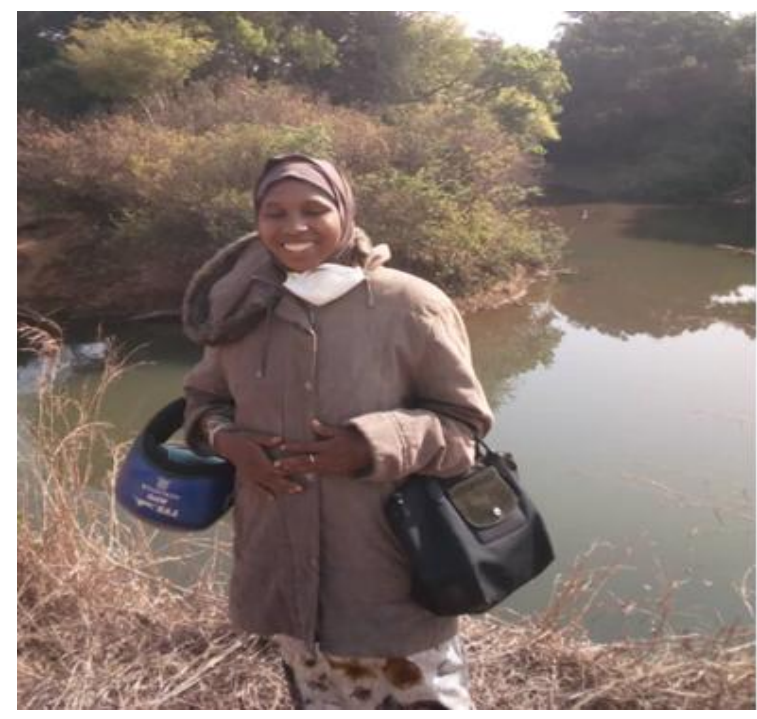

b) Water source for irrigation

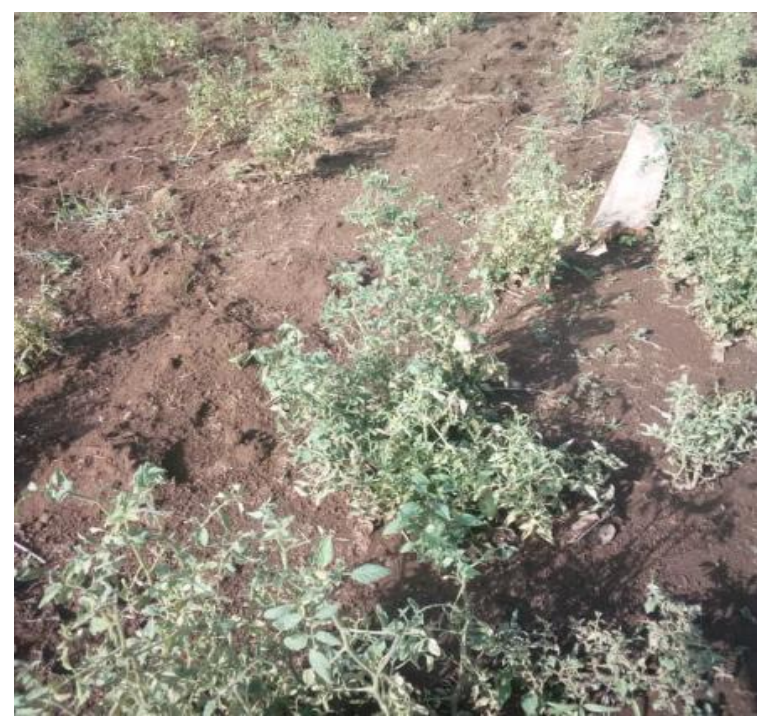

c) Tomato cultivation 
ISSN (online): 2581-3048

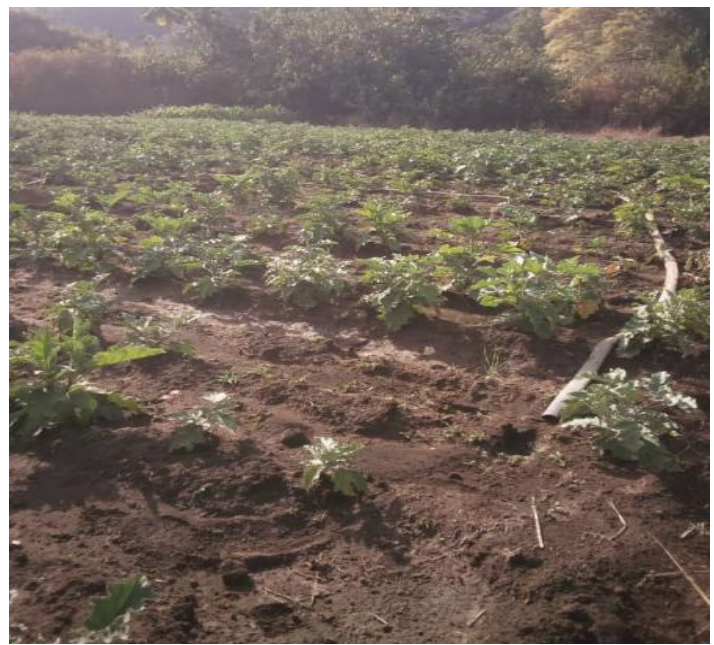

d) Eggplant culture

\section{b. Work materials}

As part of this work, we used the following materials: software (RETScrem, QGIS, AutoCAD), charts and various tools (computer, GPS, decameter, centimeter, string, staff and the level bezel).

\subsection{Methods}

The methodology adopted for this work is based on: the field survey, the sizing of the drip irrigation system and the photovoltaic pumping system, the sizing of the photovoltaic field. The working hypotheses for this purpose are as follows: the crops on the site are market gardens with a water requirement of $60 \mathrm{~m} 3 /$ d.ha. Tomato and eggplant are crops chosen for drip irrigation; the pumping system is over the sun; the pressure drops correspond at most to $10 \%$ of the total geometric height.

The sizing of the irrigation system, taking into account the rainfall of the drippers $(\mathrm{Pl}, \mathrm{mm} / \mathrm{h})$, the evapotranspiration (Eot, $\mathrm{mm} / \mathrm{d}$ ), the irrigation time per day $(\mathrm{tj}, \mathrm{h} / \mathrm{d}$ ) and the water requirement of a crop (Etc, $1 / \mathrm{s}$ ) consists in evaluating: the daily photovoltaic pumping capacity $(\mathrm{Cj}, \mathrm{m} 3 / \mathrm{d})$, as well as the fundamental dimensions: the Length of a boom, the Number of booms per sector, the Total number of booms, the Number of drippers per boom, the Number of pairs of drippers per boom and the Number of drippers per boom [13, 14].

The sizing of the pumping system, taking into account the daily photovoltaic pumping capacity $(\mathrm{Cj}, \mathrm{m} 3 / \mathrm{d})$, the fundamental dimensions included in the Total Manometric Height (HMT) solar irradiation, consists in: determining the maximum peak power, the maximum peak flow and choose a standard pump type and power capable of fulfilling the requirements and calculate the daily energy required for the

Volume 5, Issue 5, pp 143-149, May-2021

https://doi.org/10.47001/IRJIET/2021.505027

operating conditions. To validate the results of the long sizing process of our photovoltaic pumping system, we compared the value of the peak power obtained by numerical calculation and that obtained by measurement in the manufacturer's chart [16].

The sizing of the photovoltaic field and choice of solar panels, consists in choosing the inclination of the field, estimating the minimum sunshine during the period of operation, estimating the approximate efficiency of the field and determining the capacity, in peak watts, that must be have the field and determine the field configuration and readjust according to the specifications of the modules [17].

\section{RESULTS AND DISCUSSIONS}

\subsection{Results}

The various results obtained during this study relate to: the meteorological parameters of the study area, the water requirements, the pumping and storage capacities, the geometric dimensions of the drip irrigation system, the dimensions of the pumping system, the characteristics of the photovoltaic field and the installation diagram of the system.

\section{a. Meteorological parameters of the study area}

The meteorological parameters of the study area are shown in figures 2, for their proper interpretation.
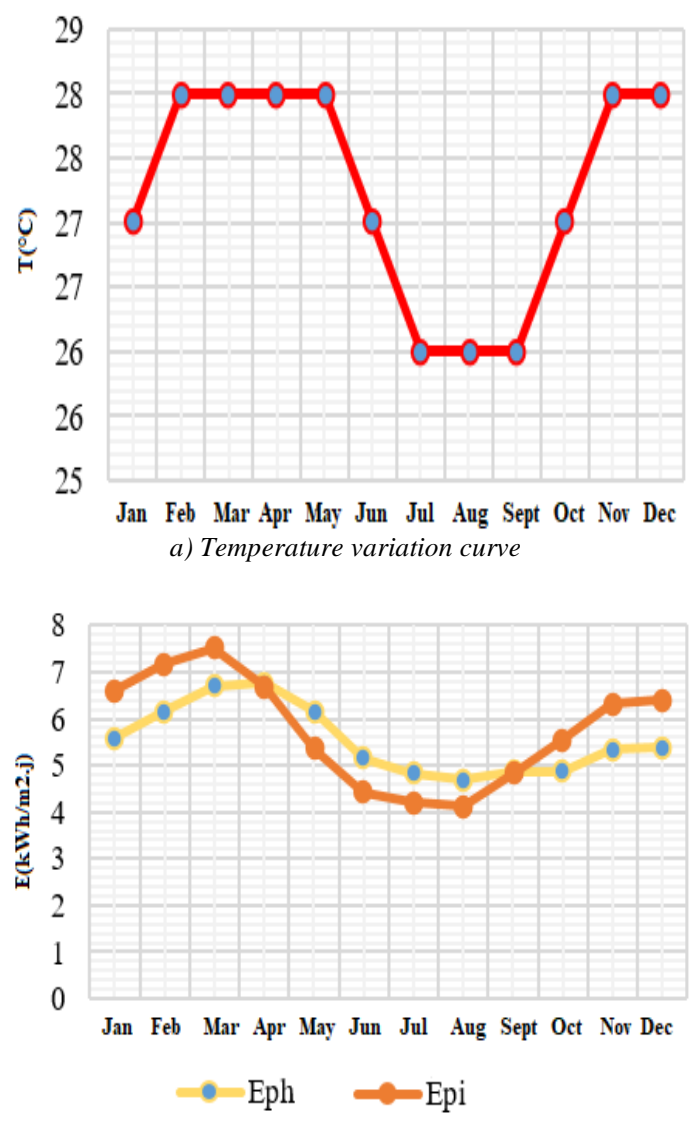

b) Sunshine variation curve 
ISSN (online): 2581-3048

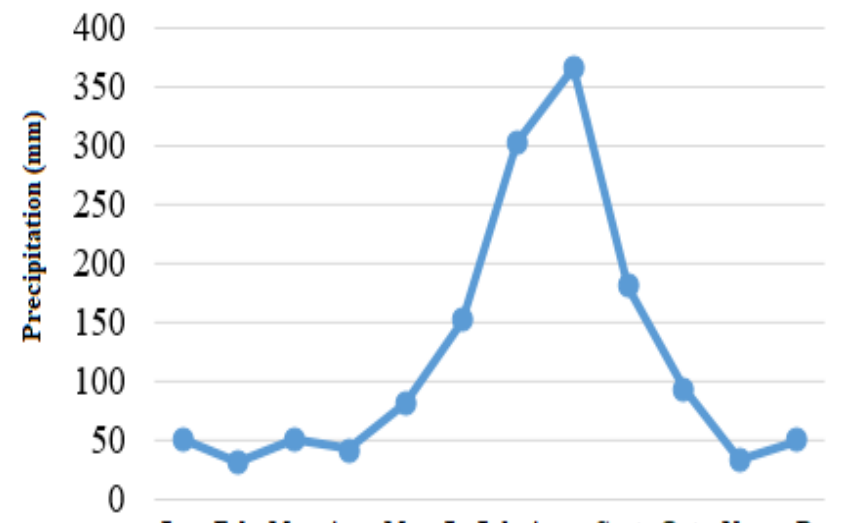

Jan Feb Mar Apr May Ju Jul Aug Sept Oct Nor Dec

c) Precipitation variation curve

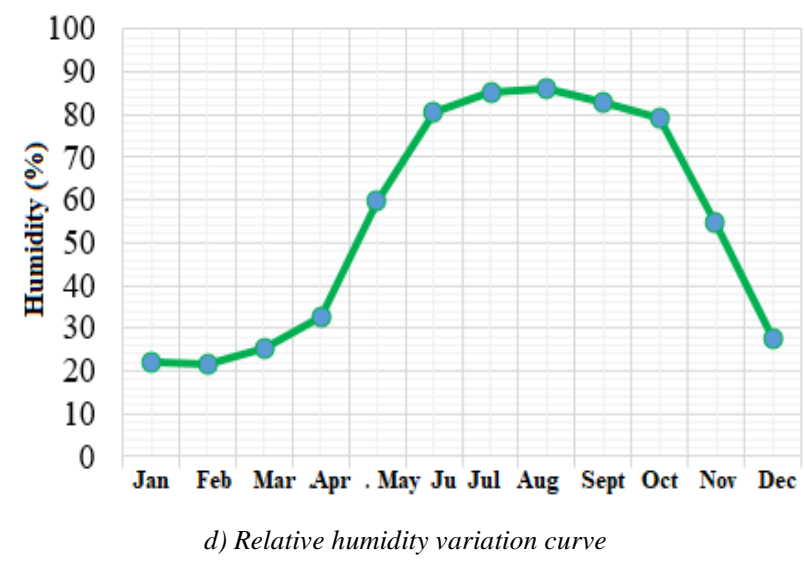

Figure 2: Meteorological parameters of the study area

\section{b. Pumping and storage capacities (crop water requirements)}

Based on the calculation of the plot unit as well as the number of plots of the 7 ha of the study area made it possible to determine the basic dimensions of the study plot, evaluated at a length of $205 \mathrm{~m}$ by $114 \mathrm{~m}$ wide, an area of $23,370 \mathrm{~m}^{2}$. It is subdivided into four (4) watering sectors. Its fundamental dimensions are as follows: Wetted length of a sector $\left(\mathrm{L}_{\mathrm{m}}=\right.$ $112 \mathrm{~m})$, wetted width of a sector $\left(l_{\mathrm{m}}=50 \mathrm{~m}\right)$ and the number of sectors $\mathrm{N}_{\mathrm{s}}=4$, (figure 3 ).

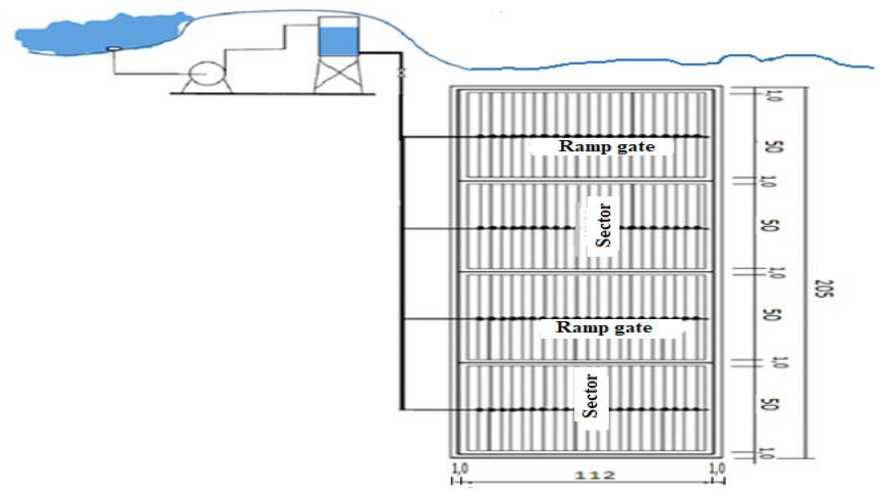

Figure 3: Development plan of a $23370 \mathrm{~m}^{2}$ plot of the operating area
The crop water requirements and other technical parameters for calculating these crop water requirements are shown in Table 1.

\section{Table 1: Crop water requirements}

\begin{tabular}{|l|c|c|c|}
\hline \multicolumn{1}{|c|}{ Designation } & Symbol & Value & Unit \\
\hline Area of the zone & $\mathrm{S}$ & 7 & $\mathrm{ha}$ \\
\hline Rainfall potential & $\mathrm{P}_{1}$ & 16.67 & $\mathrm{~m}^{3} / \mathrm{h} . \mathrm{ha}$ \\
\hline $\begin{array}{l}\text { Reference } \\
\text { evapotranspiration }\end{array}$ & $\mathrm{E}_{\mathrm{to}}$ & 60 & $\mathrm{~m}^{3} / \mathrm{j} . \mathrm{ha}$ \\
\hline Irrigation time per day & $\mathrm{t}_{\mathrm{i}}$ & 4 & $\mathrm{~h} / \mathrm{j}$ \\
\hline $\begin{array}{l}\text { Water requirement of a } \\
\text { crop }\end{array}$ & $\mathrm{B}_{\mathrm{ec}}$ & 110.83 & $\mathrm{~L} / \mathrm{s}$ \\
\hline Effective flow & $\mathrm{Q}_{\mathrm{e}}$ & 10.36 & $\mathrm{~L} / \mathrm{s}$ \\
\hline Storage capacity per day & $\mathrm{C}_{\mathrm{sti}}$ & 149.22 & $\mathrm{~m}^{3} / \mathrm{j}$ \\
\hline Daily pumping capacity & $\mathrm{C}_{\mathrm{ip}}$ & 175.55 & $\mathrm{~m}^{3} / \mathrm{j}$ \\
\hline Hourly pumping capacity & $\mathrm{C}_{\mathrm{hp}}$ & 25.08 & $\mathrm{~m}^{3} / \mathrm{h}$ \\
\hline Number of plots & $\mathrm{N}_{\mathrm{p}}$ & 3.00 & $\mathrm{sans}$ \\
\hline Number of tanks & $\mathrm{N}_{\mathrm{r}}$ & 3.00 & $\mathrm{sans}$ \\
\hline $\begin{array}{l}\text { Unit storage capacity per } \\
\text { day }\end{array}$ & $\mathrm{C}_{\mathrm{ust}}$ & 50 & $\mathrm{~m}^{3} / \mathrm{j}$ \\
\hline Tank volume pumping & $\mathrm{V}_{\mathrm{r}}$ & 56 & $\mathrm{~m}^{3}$ \\
\hline $\begin{array}{l}\text { Number of } \\
\text { stations }\end{array}$ & $\mathrm{N}_{\mathrm{sp}}$ & 3.00 & - \\
\hline $\begin{array}{l}\text { Daily unit capacity of a } \\
\text { pumping station }\end{array}$ & $\mathrm{C}_{\mathrm{ujsp}}$ & 58.52 & $\mathrm{~m}^{3} / \mathrm{j}$ \\
\hline
\end{tabular}

\section{c. Sizing of the drip irrigation system}

The determined drip irrigation system sizing parameters are shown in table 2.

Table 2: Dimensions of the drip irrigation system

\begin{tabular}{|l|c|c|l|}
\hline Designation & Symbol & Value & Unit \\
\hline Gross area of the plot & $\mathrm{S}_{\mathrm{b}}$ & 2.33 & ha \\
\hline Gross area of the plot & $\mathrm{S}$ & 233333 & $\mathrm{~m}^{2}$ \\
\hline Number of sectors & $\mathrm{Ns}$ & 4 & - \\
\hline $\begin{array}{l}\text { Number of ramps per } \\
\text { sector }\end{array}$ & $\mathrm{N}_{\mathrm{r} / \mathrm{s}}$ & 67 & - \\
\hline Total number of ramps & $\mathrm{N}_{\mathrm{tr}}$ & 268 & - \\
\hline $\begin{array}{l}\text { Number of drippers per } \\
\text { boom }\end{array}$ & $\mathrm{N}_{\mathrm{g} / \mathrm{r}}$ & 63 & - \\
\hline $\begin{array}{l}\text { Number of pairs of } \\
\text { drippers per boom }\end{array}$ & $\mathrm{N}_{\mathrm{pg}}$ & 31 & - \\
\hline
\end{tabular}

\section{d. Sizing of the pumping system}

The sizing results of the pumping system for drip irrigation are given in Table 3.

Table 3: Dimensions of the pumping system

\begin{tabular}{|l|c|c|c|}
\hline \multicolumn{1}{|c|}{ Designation } & Parameter & Value & Unit \\
\hline $\begin{array}{l}\text { Total Manometric } \\
\text { Height }\end{array}$ & HMT & 10.45 & $\mathrm{~m}$ \\
\hline $\begin{array}{l}\text { Daily flow of a } \\
\text { pumping station }\end{array}$ & $\mathrm{Q}_{\mathrm{jsp}}$ & 58.52 & $\mathrm{~m}^{3} / \mathrm{j}$ \\
\hline
\end{tabular}


ISSN (online): 2581-3048

\begin{tabular}{|l|c|l|l|}
\hline $\begin{array}{l}\text { Hourly flow rate of a } \\
\text { pumping station }\end{array}$ & $\mathrm{Q}_{\mathrm{hsp}}$ & 14.20 & $\mathrm{~m}^{3} / \mathrm{h}$ \\
\hline $\begin{array}{l}\text { Daily hydraulic } \\
\text { energy }\end{array}$ & $\mathrm{E}_{\mathrm{h}}$ & 1666.34 & $\mathrm{Wh} / \mathrm{j}$ \\
\hline $\begin{array}{l}\text { Energy consumed by } \\
\text { the motor pump }\end{array}$ & $\mathrm{E}_{\mathrm{MP}}$ & 4443.58 & $\mathrm{Wh} / \mathrm{j}$ \\
\hline Controller power & $\mathrm{P}_{\text {cont }}$ & 4677.46 & $\mathrm{Wh} / \mathrm{j}$ \\
\hline $\begin{array}{l}\text { Peak power of the } \\
\text { PV system }\end{array}$ & $\mathrm{P}_{\mathrm{C}}$ & 109082 & $\mathrm{Wh} / \mathrm{j}$ \\
\hline Peak PV system flow & $\mathrm{Q}_{\mathrm{C}}$ & 58.52 & $\mathrm{~m}^{3} / \mathrm{j}$ \\
\hline $\begin{array}{l}\text { Maximum hourly } \\
\text { flow rate of the PV } \\
\text { system }\end{array}$ & $\mathrm{Q}_{\max }$ & 7,78 & $\mathrm{~m}^{3} / \mathrm{h}$ \\
\hline
\end{tabular}

area. The analysis of the variation of these curves justifies the choice of the period (December to April) of irrigation by the drip system of the selected vegetable crops. This period corresponds to a temperature which varies between $27^{\circ} \mathrm{C}$ and $28^{\circ} \mathrm{C}$, with an annual average temperature of $27.8^{\circ} \mathrm{C}$ (curve a). The variations in solar irradiation during this period of operation on the horizontal plane and the inclined plane of $15^{\circ}$ are respectively $\left(5.38 \mathrm{kWh} / \mathrm{m}^{2} . \mathrm{j}\right.$ and $\left.6.4 \mathrm{kWh} / \mathrm{m}^{2} . \mathrm{j}\right)$ in December and $\left(6.76 \mathrm{kWh} / \mathrm{m}^{2} . \mathrm{j}\right.$ and $\left.6.69 \mathrm{kWh} \mathrm{m}^{2} . \mathrm{j}\right)$ in april. The averages during the period are: $6.12 \mathrm{kWh} / \mathrm{m}^{2} . \mathrm{j}$ on the horizontal plane and $6.87 \mathrm{kWh} / \mathrm{m}^{2} . \mathrm{j}$ on an inclined plane (curve b); which justifies the option of tilting the solar modules at an angle of $15^{\circ}$ to the south, thus promoting optimal operation of the photovoltaic field.

The variation in precipitation during the operating period is $49 \mathrm{~mm}$ in December and $42 \mathrm{~mm}$ in April, it is the season of low precipitation of the site during the year (curve c), which requires the installation of the irrigation system. The annual average precipitation is $119.08 \mathrm{~mm}$. Humidity varies from $27.4 \%$ in December and $32.8 \%$ in April, with an annual average of $54.73 \%$ (curve d).

\section{b. Pumping and storage capacities (crop water requirements)}

The cultivable area for irrigation is 2.333 hectares subdivided into 4 sectors, with a daily irrigation time of 4 hours. Thus, the daily crop water requirement for each plot is $50 \mathrm{~m}^{3}$.

\section{c. Sizing of the drip irrigation system}

The number of ramps calculated for each sector is 67 with a total of 268 ramps for the entire cultivable area. The number of drippers is 63 per boom and for 31 pairs of drippers per boom table2.

\section{d. Sizing of the pumping system}

Table 4: Sizing of the photovoltaic field

\begin{tabular}{|l|c|c|c|}
\hline \multicolumn{1}{|c|}{ Characteristics } & Symbol & $\begin{array}{c}\text { Val } \\
\text { ue }\end{array}$ & Units \\
\hline Number of panels & $\mathrm{N}_{\mathrm{p}}$ & 15 & - \\
\hline Series connection & $\mathrm{B}_{\mathrm{s}}$ & 5 & - \\
\hline Parallel connection & $\mathrm{Bp}$ & 3 & - \\
\hline Total PV array power & $\mathrm{P}_{\mathrm{PV}}$ & $\begin{array}{c}472 \\
8.24\end{array}$ & $\mathrm{~W}$ \\
\hline $\begin{array}{l}\text { Series connection } \\
\text { voltage }\end{array}$ & $\mathrm{U}_{\mathrm{Bs}}$ & $\begin{array}{c}199 . \\
0\end{array}$ & $\mathrm{~V}$ \\
\hline $\begin{array}{l}\text { Parallel connection } \\
\text { current }\end{array}$ & $\mathrm{I}_{\mathrm{Bp}}$ & $\begin{array}{c}23.7 \\
6\end{array}$ & $\mathrm{~A}$ \\
\hline
\end{tabular}

\subsection{Discussions}

\section{a. Meteorological parameters of the study area}

The curves in Figure 3.1 show the annual average variations of some important meteorological parameters of the study

The Total Manometric Head (HMT) is $10.45 \mathrm{~m}$ for each pump to be installed, with a daily flow rate of $58.517 \mathrm{~m} 3$ or $14.20 \mathrm{~m}^{3} / \mathrm{h}$ for each pump. The energy consumed by the motor pump $4443.58 \mathrm{Wh} / \mathrm{d}$, the power of the controller is 4677.46 $\mathrm{Wh} / \mathrm{d}$. Thus, the calculated peak power of the PV system is $1090.82 \mathrm{Wh} / \mathrm{d}$ (table 3)

\section{e. Sizing of the photovoltaic field}

The type of solar panel chose the 80-cell Cip with a power range that varies from 315 to $330 \mathrm{Wp}$ (Cip-80-330, Cip-80325, Cip-80-320 and Cip-80-315). In this work, it was retained the Cip-80-315 of total peak power of the field equal to 4728.24 Wp which is immediately higher than that of the controller. The voltage per branch is UBS $=199$ volts and the total current in the parallel connection will then be IBP = 
ISSN (online): 2581-3048

23.76 A. The PV field is made up of 5 modules in series in 3 parallel branches, for a total of 15 modules.

The system installation block diagram is shown in Figure 5.

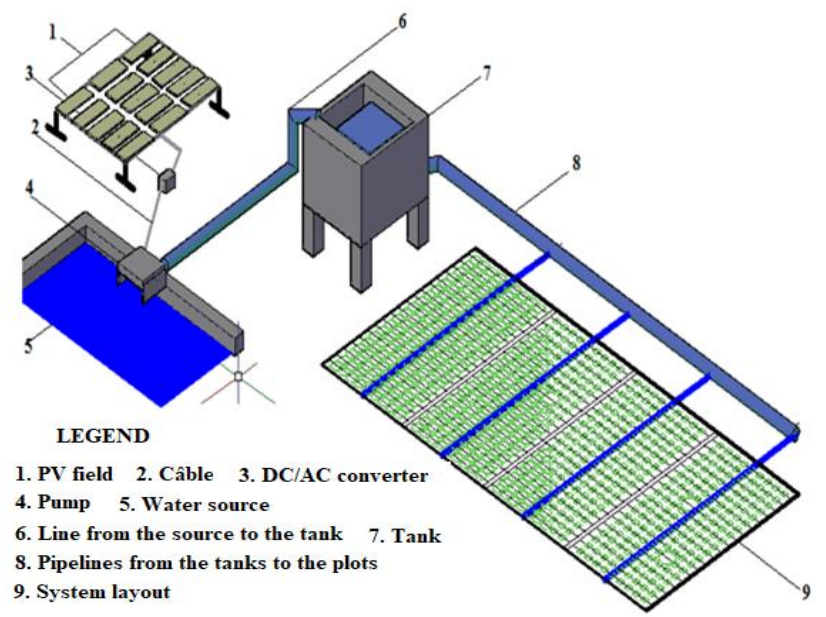

IV. CONCLUSION

As part of this study, we made a synthesis on irrigation techniques. A field visit was carried out in order to locate the cultivable areas in the area, identify the types of crops and assess the availability of water for irrigation before proceeding to the sizing of the various parameters of the drip irrigation system. Drip by photovoltaic pumping based on certain formulas, software and assumptions. This study showed that the choice and sizing of the elements of a system photovoltaic for drip irrigation requires an estimate of the needs in water. This estimate can be calculated beforehand, but ultimately it will be approached to the fact that we want to obtain autonomy in bad weather.

\section{REFERENCES}

[1] Youssef M'SADAK, Afoua MANAI, Nahed EL JANDOUBI et Mahmoud Elies HAMZA, Évaluation Expérimentale de 1'Irrigation par Aspersion Non Mécanisée dans le Contexte Tunisien, Revue Agriculture vol. 8 n¹ (2017) pp. 39-48.

[2] Lary Ligring, Etude pour la mise en place du système de pompage solaire d'un champ de neuf hectares pour une irrigation goutte à goutte à Seheba au Tchad. Mémoire master 2012, 49p.

[3] Hanafi S., Approche d'évaluation de la performance des systèmes irrigués à l'échelle des exploitations agricoles : Cas du périmètre irrigué de Borj Toumi (Vallée de la Medjerda Tunisie), Thèse de Doctorat AgroParisTech, France, 2011, 103p.

[4] EEA, Annual report 2009 and Environmental statement 2010, European Environment Agency, Denmark, 2010, 92.
[5] Hanafi S., Frija A., Jamin J.Y., Zairi A., Hamdane A., Mailhol J.C., Les performances des petites exploitations irriguées de la basse vallée de la Medjerda en Tunisie, Cahiers Agricultures, vol. 24, no 3, 2015, 170-176.

[6] Plan National d'Investissement Agricole et de Sécurité Alimentaire 2013-2017, Rapport, Ministère de l'Agriculture, République de Guinée, 2012, 101 p.

[7] Plan de Gestion des Pestes, Projet de Développement Agricole Intégré de la Guinée, Rapport, République de Guinée, Ministère de l'Agriculture 2018, 73p.

[8] Taibi Hamida, Kastali Fatima, Dimensionnement d'un réseau d'irrigation du perimetre Hessaine Wilaya de Mostaganem, Master Université Djillali Bounaama - Khemis Miliana, Algérie 2018, 97p.

[9] Ye Dofindoubê Victor, Conception, installation et évaluation d'un système d'irrigation goutte à goutte pour la production de légumes dans le village de Sonsogona. Master de l'Université Nazi boni, Burkina Faso, 2018, 66p.

[10] Module de formation, irrigation au goutte à goutte, République du Niger, Programme Nigéro - Allemand de Promotion de l'Agriculture Productive PromAP, Composante 2, Version finale, Janvier 2019, 52p.

[11] Amadou D., Cellou K., Ansoumane S., Saïdou B., and Mamby., K Study and Design of a Photovoltaic Pumping System in the Madinah Sector at Dogomet Prefecture Dabola (Guinea), European Modern Studies Journal, 2020, 4(1), pp. 130 - 137.

[12] Ansoumane SAKOUVOGUI, Younoussa Moussa BALDE, Mamadou Foula BARRY, Cellou KANTE, et Mamby KEITA, Évaluation du potentiel en biogaz de la bouse de vache, de la fiente de poule et en codigestion à Mamou, République de Guinée, Afrique SCIENCE 14(5).

[13] Jimmy Royer, Thomas Djiako, Eric Schiller, Bocar Sada Sy (1998).Pompage photovoltaïque Manuel de cours à l'intention des ingénieurs et des techniciens. Université d'Ottawa, $281 \mathrm{p}$.

[14] Mohamed Lakhdar Louazene (2015). Contribution à l'optimisation des systèmes photovoltaïques utilisés pour l'irrigation dans les zones sahariennes Application zone de Ouargla. Thèse de Doctorat en Sciences Université El Hadj Lakhdar- Batna, Algérie, $128 \mathrm{p}$.

[15] Missi Kya Tohou, Etude technique d'aménagement d'un périmètre hydro agricole de 50 ha par le système goutte à goutte en phase d'avant-projet détaillé. Cas de Pensa, Mémoire de fin d'étude, 2iE Ouagadougou - Burina Faso, 2015, 30p.

[16] HADJOU SMIR Hachmi et CHOGUEUR Amine, Etude technico-économique de l'irrigation par 
ISSN (online): 2581-3048

Volume 5, Issue 5, pp 143-149, May-2021

https://doi.org/10.47001/IRJIET/2021.505027

pompage solaire photovoltaïque, d'une palmeraie de palmiers. Etude de cas. Mémoire de fin d'études supérieures, Université ABOU BEKR BELKAID, 2018, 113p.

[17] Poirée M.et Ollier Ch., Irrigation : Les Réseaux d'Irrigation, Théorie, Technique et Economie des Arrosages. Edition Eyrolles, Paris - 1981, 503p.

\section{AUTHORS BIOGRAPHY}

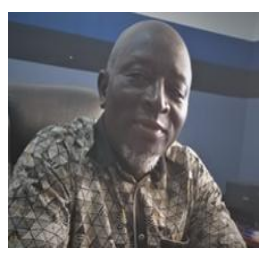

Amadou Diarra, Doctor $\mathrm{PhD}$ from the Prague Technical College, Czech Rep. Czech, Lecturer, Teacher-researcher, Department of Mechanical Engineering, Polytechnic Institute, Gamal Abdel Nasser University of Conakry.

Research area: Machines and Energy Systems; Industrial Refrigeration and Air Conditioning; Energy conversion in thermal and hydraulic machines.

Email address: drdiarramadou@ gmail.com

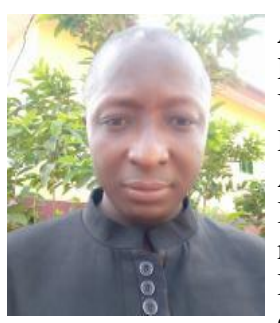

Ansoumane Sakouvogui, Doctor $\mathrm{PhD}$ from Gamal Abdel Nasser University in Conakry, Assistant Professor of the Universities of the African and Malagasy Council for Higher Education, Lecturerresearcher at the Energy Department of the Higher Institute of Technology of Mamou.
Areas of research: Renewable Energies, Solar Energy Conversion, Bioconversion, Small Hydropower and Energy-Environment.

Email address: ansoumane2015@gmail.com

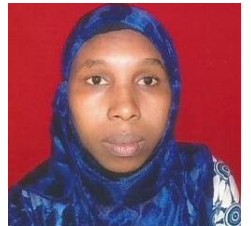

Mariame BAH, Assistant, Teacher-researcher, Mechanical Design and Manufacturing Department of the Higher Institute of Technology of Mamou.

Student in Master of Energy and Environmental Systems, Applied Energy Teaching and Research Laboratory of Gamal Abdel Nasser University in Conakry. Research area: Energy Systems and Hydraulic Machines.

Email address:b.mariama45@gmail.com

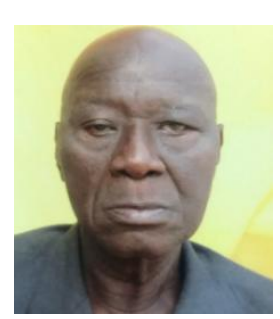

Mamby Keïta, Doctor Ph.D Baku State University, Azerbaijan Former USSR, Full Professor of Universities, Teacher-researcher, Laboratory of Teaching and Research in Applied Energy, Department of Physics, Faculty of Sciences of Gamal Abdel Nasser University in Conakry.

Research area: Renewable Energies. Courses provided: Electronic, Photovoltaic, Bioconversion, and Hydroelectricity. Currently Deputy Director General of Higher Education. Honorary distinctions: Honorary Officer of the African and Malagasy Council for Higher Education. Email address: mamby1952@gmail.com

\section{Citation of this Article:}

Amadou Diarra, Ansoumane Sakouvogui, Mariame BAH, Mamby Keïta, "Study and Sizing of a Drip Irrigation System by Photovoltaic Pumping in the District of Bellel, Mamou Prefecture" Published in International Research Journal of Innovations in Engineering and Technology - IRJIET, Volume 5, Issue 5, pp 143-149, May 2021. Article DOI https://doi.org/10.47001/IRJIET/2021.505027 